\title{
The Effect of Trypan Blue on the Serum Proteins of the Fetal Rat'
}

\author{
ALLAN R. BEAUDOIN AND DOROTHY KAHKONEN 2 \\ Department of Anatomy, The University of Michigan Medical School, \\ Ann Arbor, Michigan
}

\begin{abstract}
Pregnant rats were injected intraperitoneally with a teratogenic dose of trypan blue $(14 \mathrm{mg} / 100 \mathrm{~g}$ or $20 \mathrm{mg} / 100 \mathrm{~g}$ body weight) on the eighth day of gestation. Fetal blood was collected from control and experimental fetuses on the twentieth day of pregnancy. Serum was obtained from pooled blood samples of two to three fetuses. Paper electrophoresis was carried out in a Spinco model $R$ system using barbital buffer at $\mathrm{pH}$ 8.6. The paper strips were subsequently stained with bromphenol blue and their density measured in a Spinco Analytrol to determine the relative concentration of each component. Total protein was measured in a Bausch and Lomb Serum Protein Meter. The predominant malformations seen in abnormal fetuses were apparent anophthalmia, 59\%; hydrocephalus, 37\%; and exencephaly, $19 \%$. Other malformations were noted but with less frequency. Twentyday fetuses from trypan blue treated mothers had a significantly lower total protein concentration $(1.50 \mathrm{~g} / 100 \mathrm{ml})$ than control fetuses $(1.95 \mathrm{~g} / 100 \mathrm{ml})$. A comparison of the absolute protein concentration of the serum fractions revealed significant differences between control and experimental fetuses in beta globulin, alpha-1 globulin, and albumin. In each instance the absolute concentration was less in the fraction from fetuses of trypan blue treated mothers. Fetal gamma, alpha-2, and alpha-3 globulins were not affected by the maternal treatment.
\end{abstract}

The disazo dye, trypan blue is known to cause alterations in the serum proteins of the pregnant rabbit when administered either as subcutaneous injections prior to and during pregnancy (Langman and van Drunen, '59) or, as a single subcutaneous injection on the second day of gestation (Beaudoin and Ferm, '61). Both papers report a significant increase in the alpha and beta globulin concentration. This increase occurred during the first ten days of pregnancy, a time critical to embryogenesis. Langman and van Drunen reported $39 \%$ resorptions and $17 \%$ of the survivors malformed at autopsy, proof that a teratogenic dose of trypan blue was employed. Beaudoin and Ferm did not carry their experiments to the end of gestation, however, their dose was based on a teratogenic concentration previously reported by Ferm ('56).

Alterations of serum protein composition, following trypan blue treatment, is not limited to the rabbit. Yamada ('59) and Paoletti et al. ('62) reported serum protein changes in male rats treated with heavy doses of trypan blue. In each paper reference is made to an "abnormal" protein band migrating in close association with the alpha-2 globulin during paper electrophoresis. No marked changes were reported for any other globulin. Dijkstra and Gillman, ('60) reported a faint band that may or may not be related to the "abnormal" protein reported by Yamada. The band observed by Dijkstra and Gillman, however, was not present in every sample. It has also been demonstrated that teratogenic doses of trypan blue administered to the rabbit causes alterations in the protein composition of the yolk sac fluid of nine-day old embryos which mimic those of the maternal serum protein alteration (Hommes, '59; Beaudoin and Ferm, '61). The relationship between the maternal serum proteins and the proteins found in the yolk sac and fetus in the rabbit have been reviewed by Hemmings and Brambell ('61). Apparently free passage of maternal proteins across the yolk sac is possible, certainly albumin and gamma globulins can do so. In addition, it is probable that maternal albumin and most maternal globulins are able to pass to the fetal circula-

1 Supported by research grant AM-05603-03 from the National Institute of Metabolic Diseases, Public Health Service, U. S. Department of Health, Education, and Welfare.

2 Medical Student Research Fellow. 
tion, although not with equal degrees of freedom.

The present investigation is based on the assumption that a similar relationship between maternal serum proteins and fetal serum proteins may exist in the rat, as described above for the rabbit. The aim of this study is to determine if any alterations can be detected in the serum proteins of fetuses whose mothers have been subjected to the teratogen trypan blue.

\section{MATERIALS AND METHODS}

Virgin females of Wistar Albino rats (Albino Farms, Red Bank, N. J.) were used in this study. The animals were maintained on an ad libitum diet of Rockland Complete Rat Diet with supplementary feedings of lettuce and orange slices. Day 0 of pregnancy was considered to begin on the morning on which sperm was found in the vaginal smear. Pregnant rats were given a single intraperitoneal injection of a $2 \%$ aqueous solution of trypan blue on the eighth day of gestation, either $14 \mathrm{mg} / 100 \mathrm{~g}$ or $20 \mathrm{mg} / 100 \mathrm{~g}$ body weight. Pregnancy was terminated on the twentieth day and blood was obtained from the mother and her fetuses. Maternal blood was obtained by cardiac puncture. Fetal blood was collected either by making an incision directly into the heart or by cutting the major vessels of the neck and collecting the blood in a shallow depression in a piece of lucite. The blood was transferred to centrifuge tubes using a $1 \mathrm{ml}$ syringe, without a needle. Blood was pooled from two to three fetuses to form a single sample for analysis. Fetuses from treated mothers were separated into two groups: (1) those visibly malformed and (2) those apparently normal. Blood from each group was treated separately throughout the experiment.

Serum was obtained and its total protein content measured with a Bausch and Lomb Serum Protein Meter. Paper electrophoresis was carried out in a Spinco cell using Spinco B-2 buffer (Veronal at $\mathrm{pH}$ 8.6; 0.075 ionic strength). The paper strips were run for 17 hours at $3.5 \mathrm{ma}$. The strips were subsequently stained with bromphenol blue and their density was measured in a Spinco Analytrol (recording densitometer) to determine the rela- tive concentration of each component. Control animals were run concurrently with the experimentals.

\section{RESULTS}

Table 1 is a presentation of the effects of trypan blue on the offspring of the mothers used in this study. It is evident that the dosages employed were teratogenic. There was no marked difference in the results obtained with the two levels of treatment used so that, unless otherwise stated, the two experimental groups are combined in future analyses. The predominant malformations seen in the survivors were apparent anophthalmia, 59\%; hydrocephalus, 37\%; and exencephaly, $19 \%$. Various other defects such as absence of tail, hydronephrosis, spina bifida with myeloschisis, and gastroschisis were also observed, but with much smaller frequency. The heart was not examined critically although defects are known to occur following trypan blue treatment (Fox and Goss, '56).

The relationship between the position of the fetus within the uterus and its response to the treatment is shown in table 2 . For this analysis each uterine horn was divided into an ovarian one-half and a cervical one-half. The left uterine horn showed an equal distribution in the number of resorbed and dead fetuses. Very little difference was noted in the number of survivors malformed and in the total percentage of implantation sites affected by the treatment. However, the right uterine horn exhibited differences in the

Fig. 1 The two parts of this figure are reproductions of stained paper strips and their tracings from the Spinco Analytrol obtained after electrophoresis of maternal rat serum. Six protein components were detected in the rat serum: $\gamma$, gamma globulin; $\beta$, beta globulin; $a^{1}$, alpha- 1 , $a^{2}$ alpha-2, $\alpha^{3}$ alpha-3 globulins; and $a l b$, albumin. The arrows indicate the point of origin.

Top graph and paper strip. This represents the typical appearance of the electrophoretic pattern of maternal serum obtained on the tenth day of gestation from an untreated mother.

Bottom graph and paper strip. This represents the typical aprearance of the electrophoretic pattern of maternal serum obtained on the tenth day of gestation from a mother treated with trypan blue. The heavy line at the point of origin is trypan blue: the dye does not migrate during electrophoresis. 
TRYPAN BLUE AND FETAL SERUM PROTEINS

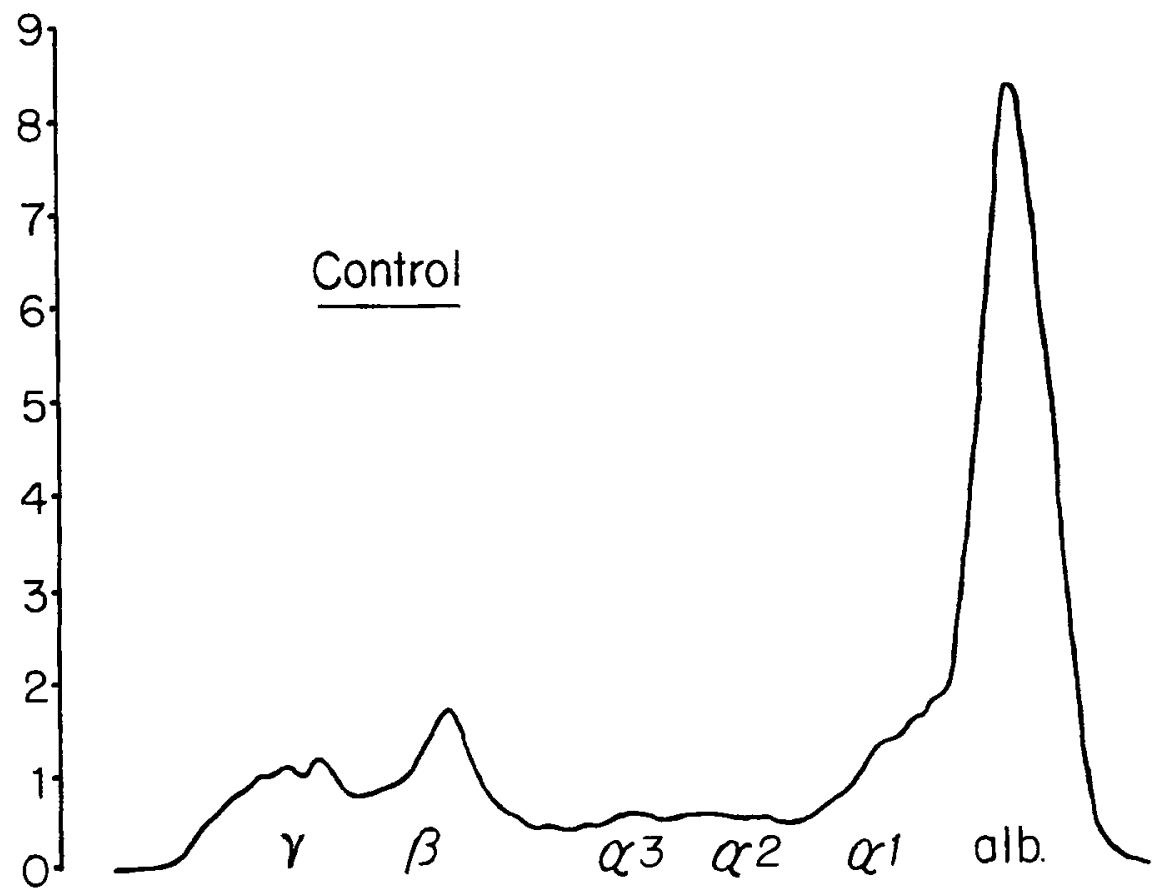

$\uparrow$
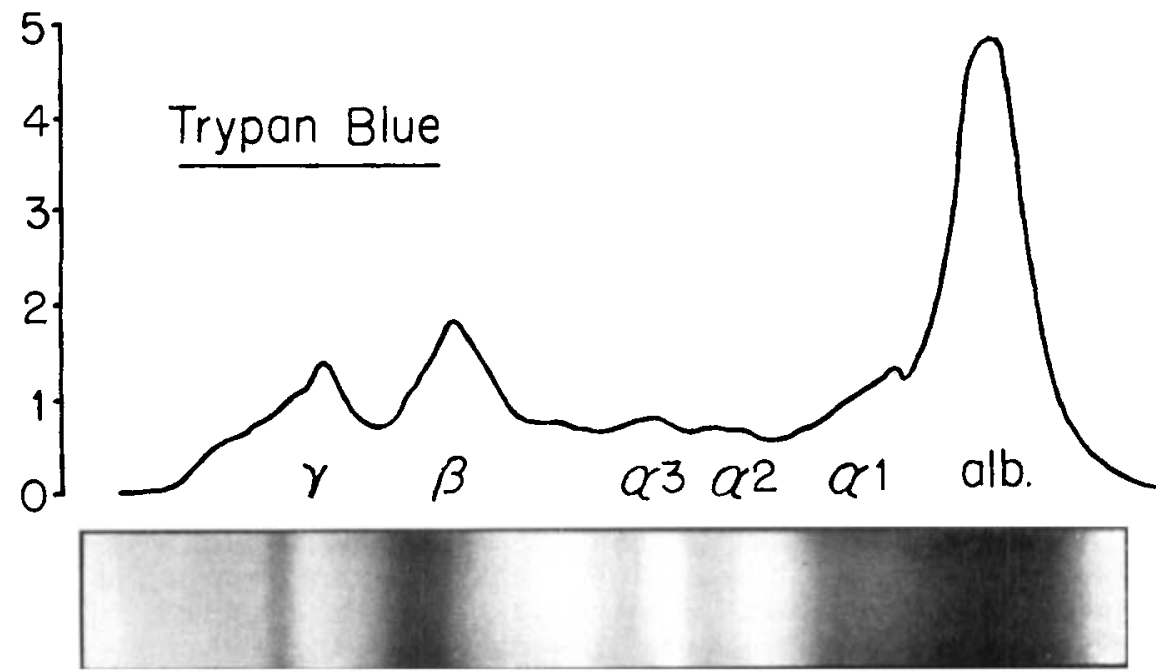

$\uparrow$

Figure 1 
TABLE 1

The effect of intraperitoneal injection of trypan blue into female rats on the eighth day of gestation

\begin{tabular}{lccccr}
\hline $\begin{array}{c}\text { Dose of } \\
\text { trypan blue }\end{array}$ & $\begin{array}{c}\text { Number } \\
\text { of mothers }\end{array}$ & $\begin{array}{c}\text { Number of } \\
\text { implantation } \\
\text { sites }\end{array}$ & $\begin{array}{c}\text { Number } \\
\text { and }(\%) \\
\text { resorbed }\end{array}$ & $\begin{array}{c}\text { Number } \\
\text { and }(\%) \\
\text { survivors } \\
\text { malformed }\end{array}$ & $\begin{array}{c}\% \\
\text { implantation } \\
\text { sites } \\
\text { affected by } \\
\text { treatment }\end{array}$ \\
\hline $14 \mathrm{mg} / 100 \mathrm{~g}$ & 19 & 231 & $125(54)$ & $68(64)$ & 83.5 \\
$20 \mathrm{mg} / 100 \mathrm{~g}$ & 10 & 153 & $83(54)$ & $43(62)$ & 82.5 \\
Controls & 10 & 135 & $2(1.5)$ & 0 & 1.5 \\
\hline
\end{tabular}

TABLE 2

Effect of trypan blue on implantation sites and surviving offsprings

\begin{tabular}{|c|c|c|c|c|c|}
\hline & \multicolumn{2}{|c|}{$\begin{array}{l}\text { Number of } \\
\text { implantation } \\
\text { sites }\end{array}$} & $\begin{array}{l}\text { Number } \\
\text { and (\%) } \\
\text { of sites } \\
\text { resorbed } \\
\text { or dead }\end{array}$ & $\begin{array}{l}\text { Number } \\
\text { and (\%) } \\
\text { survivors } \\
\text { malformed }\end{array}$ & $\begin{array}{c}\% \text { of } \\
\text { implantation } \\
\text { sites } \\
\text { affected by } \\
\text { treatment }\end{array}$ \\
\hline $\begin{array}{l}\text { Left horn } \\
\text { Ovarian half } \\
\text { Cervical half }\end{array}$ & \multicolumn{2}{|c|}{$\begin{array}{l}96 \\
96\end{array}$} & $\begin{array}{l}53(55) \\
53(55)\end{array}$ & $\begin{array}{l}26(60) \\
24(56)\end{array}$ & $\begin{array}{l}82.4 \\
80.3\end{array}$ \\
\hline Totals & \multicolumn{2}{|c|}{192} & $106(55)$ & $50(58)$ & 81.3 \\
\hline $\begin{array}{l}\text { Right horn } \\
\text { Ovarian half } \\
\text { Cervical half }\end{array}$ & & & $\begin{array}{l}49(51) \\
56(58)\end{array}$ & $\begin{array}{l}36(74) \\
25(60)\end{array}$ & $\begin{array}{l}88.5 \\
84.5\end{array}$ \\
\hline Totals & \multicolumn{2}{|c|}{192} & $105(55)$ & $61(67)$ & 86.5 \\
\hline \multicolumn{6}{|c|}{$\begin{array}{l}1 \text { Includes } 29 \text { mothers treated with } 14 \mathrm{mg} / 100 \mathrm{~g} \text { and } 20 \mathrm{mg} / 100 \mathrm{~g} \text {. } \\
2 \text { Percentage resorbed, dead, and malformed. }\end{array}$} \\
\hline \multicolumn{6}{|c|}{ TABLE 3} \\
\hline \multicolumn{6}{|c|}{ Litter size, and fetal and placental weights in treated and control rats } \\
\hline Treatment & \multicolumn{3}{|c|}{$\begin{array}{c}\text { Mean } \\
\text { number of } \\
\text { implantation } \\
\text { sites per } \\
\text { litter }\end{array}$} & $\begin{array}{l}\text { Fetal weight } \\
\text { in grams }{ }^{1}\end{array}$ & $\begin{array}{l}\text { Placental } \\
\text { weight } \\
\text { in grams }\end{array}$ \\
\hline Control & 10 & \multicolumn{2}{|c|}{$13.5 \pm 2.8$} & $3.62 \pm 0.08$ & $0.526 \pm 0.054$ \\
\hline $\begin{array}{l}\text { Trypan blue } \\
\quad 14 \mathrm{mg} / 100 \mathrm{~g}\end{array}$ & 19 & \multicolumn{2}{|c|}{$\begin{array}{l}12.2 \pm 2.2 \\
P=0.20\end{array}$} & $\begin{array}{l}3.37 \pm 0.42 \\
P=<0.001\end{array}$ & $\begin{array}{l}0.513 \pm 0.083 \\
P=0.90\end{array}$ \\
\hline $20 \mathrm{mg} / 100 \mathrm{~g}$ & 10 & \multicolumn{2}{|c|}{$\begin{array}{l}15.3 \pm 2.8 \\
P=0.20\end{array}$} & $\begin{array}{l}3.17 \pm 0.61 \\
P=<0.001\end{array}$ & - \\
\hline
\end{tabular}

1 With standard deviation.

distribution of implantation sites resorbed and dead as well as in the number of survivors malformed. On the one hand, more fetuses were resorbed or dead in the cervical one-half while, on the other hand, the percentage of survivors malformed was greater in the ovarian one-half. As a result, the percentage of all implantation sites affected by the treatment varied only slightly between the two halves. The over- all effect of the treatment seemed to be somewhat greater in the right uterine horn. No significance is attached to this observation.

Fetal and placental weights, as well as litter size, were compared in the untreated and treated rats (table 3 ). Treatment had no effect on the total number of implantations sites observed in the control and treated mother. However, fetuses from 
dye treated mothers weighed significantly less than fetuses from control mothers. This difference in weight, between control and experimental animals, was more pronounced in the fetuses whose mothers received the highest dose ( $20 \mathrm{mg} / 100 \mathrm{~g})$ of trypan blue. Placental weights were recorded in the control and $14 \mathrm{mg} / 100 \mathrm{~g}$ groups but no significant differences were observed.

When the total protein and absolute concentration of the serum protein fractions were compared between the control and experimental fetuses several interesting observations were made (table 4). At the time of autopsy (twentieth day of gestation) there was a difference in the total protein concentration between the control fetuses $(1.95 \mathrm{~g} / 100 \mathrm{ml})$ and fetuses from trypan blue treated mothers ( 1.50 $\mathrm{g} / 100 \mathrm{ml}$ ) that is significant at the $5 \%$ level. No change was observed in gamma, alpha-3 and alpha-2 globulins, but the absolute concentrations of beta and alpha-1 globulins and albumin were significantly less than the concentrations exhibited in the control fetuses.

\section{DISCUSSION}

Very little has been written about the serum proteins during embryonic development in the rat compared with that written about fetuses of some other mammals, e.g., man, calf, and rabbit (Kekwick, '59). Practically no information is available about the interrelationships between maternal serum proteins and fetal serum proteins in the rat. A recent paper by Heim ('61) presents the most complete account that is now available concerning fetal serum proteins during rat embryonic development. However, this report lacks information on relationships between the maternal and fetal sera. Heim, through the use of paper electrophoresis, was able to identify 7 components in fetal rat serum at 17 days of gestation, the earliest stage he examined (day $1=$ the day sperm was found in the vaginal smear). The seven components described by Heim are: a fast albumin fraction, albumin, alpha-1, -2 , and -3 globulins, beta globulin, and a gamma globulin fraction. By the nineteenth day the fast albumin fraction had disappeared, by merging with the principle 
albumin component, and at that time the electrophoretic pattern of the fetal serum resembled that of maternal serum. No significant change in the mobility of the components was reported. A comparison of the relative concentration of the serum components revealed albumin to be always the major constituent. Albumin concentration is below the adult non-pregnant female level at 17 days gestation, rises above it at one day postpartum and finally attains the adult level sometime after the first postnatal month. The relative concentration of alpha-1 globulin rises during the fetal period 17 days to parturition. Just prior to birth alpha-1 globulin levels are substantially higher than in the adult non-pregnant female, although, the concentration corresponds closely to the pregnant female during the same period of gestation (Beaudoin, unpublished). Alpha-2 and alpha-3 globulins have relative concentrations that are almost twice as high in fetal rat serum as in serum from the adult non-pregnant female rat. There is a gradual fall in their concentration during the postpartum period until the adult level is reached. There is little or no change in the concentration of beta globulin from 17 days gestation to birth, the fetal values correspond closely, at all times, to those of the adult female. The concentration of gamma globulin is always lower in the rat fetus than in the adult. This agrees with the observation that the rat gains some of its immunity after birth (by way of the mother's milk) and, therefore, there is a postnatal rise in the gamma globulin fraction. The paper electrophoresis patterns of rat serum in the present investigation revealed six serum components in the 20-day fetus as well as in the adult female rat. The relative concentration of each component is in close agreement with those reported by Heim ('61). Recent immunoelectrophoretic studies of fetal rat serum proteins during late gestation have shown a gradual acquisition of serum protein components characteristic of the adult (Kelleher and Villee, '62).

Information that is available concerning the transfer of serum proteins from mother to fetus is derived primarily from immunological and tracer studies in the rabbit, guinea pig, and man. Brambell and Hemmings ('49) attempted to show passage of maternal proteins into rabbit yolk sac fluid by the use of the teratogenic disazo dye Evans blue, which binds to serum albumin. They were able to demonstrate Evans blue in the yolk sac cavity following maternal injection of the dye, which led them to the conclusion that maternal albumin did pass into the rabbit yolk sac fluid. Similar results have been reported by Ferm ('56) using another teratogenic disazo dye, trypan blue. Bramble et al. ('53) analyzed sera, exocoelomic and amniotic fluids, and stomach contents of normal fetal rabbits 25 days after copulation. They found that these fluids contained components similar to those of the maternal serum in electrophoretic mobility and in sedimentation rate in the ultracentrifuge. Using antibodies as markers they reported that both gamma and beta globulins entered the fetal circulation from immune rabbit serum injected into the uterine lumen. A possible route of passage of these serum components was proposed from uterine lumen to exocoelomic fluid to amniotic fluid to stomach and finally across the endodermal lining of the fetal gut to embryonic tissues. This would suggest that the fetal gut plays a similar role as the postnatal gut in those animals that obtain gamma globulin after birth. Hemmings and Brambell ('61) report studies with $I^{131}$ trace-labeled heterologous (bovine) and homologous proteins injected into the uterine lumen of the rabbit. Both types of serum proteins appeared in the fetal serum, although heterologous proteins were taken up at different rates than the homologous proteins [gamma $>$ albumin $>$ beta $>$ alpha, whereas homologous proteins: albumin $>$ beta $>$ alpha $>$ gamma (almost nil)].

Smith and Schechtman ('62) gave intravenous injections of either human or guinea pig serum to pregnant rabbits in experiments designed to determine whether or not the main serum protein components could pass from maternal serum into the yolk sac of the rabbit, and from the yolk sac be transferred to the embryo. They subsequently were able to identify materials with antigenicities and electrophoretic mobilities similar to those of all major components of the serum from the human 
and guinea pig in the yolk sac of the embryo. However, while they did find human proteins in the blood of the early embryo, guinea pig serum antigens could not be detected in the embryonic circulation. This observation indicates that not all heterologous protein can be transferred from mother to fetus.

Studies utilizing injections of radioactive plasma proteins from donor guinea pigs have been conducted by Dancis et al. ('57). They concluded that all identifiable serum proteins (by zone electrophoresis) are able to cross the placenta from the maternal circulation to the fetal circulation. Leissring and Anderson ('61) were able to demonstrate that guinea pigs immunized with anti-Brucella serum transferred a detectable amount of the antibody to the fetus.

Bangham et al. ('58) using $\mathbf{I}^{131}$ labeled serum proteins presented evidence that maternal albumin and gamma globulin are transferred across the placenta from mother to fetus in the rhesus monkey. Gamma globulin was found to be transferred 15 to 20 times more easily than albumin. On the other hand, alpha and beta globulins did not appear to reach the fetal circulation. Studies on the human (reviewed by Steinberg, '62; Dancis, '62; Freda, '62) have concluded that whatever gamma globulin is present at birth has all been derived from the mother for neither the placenta nor the fetus appear to produce gamma globulin. The conclusions reached about the other serum protein fractions are not so decisive. Albumin is thought to be transferred in relatively large amounts while the alpha and beta fractions at considerably slower rates. The heterogenicity of these fractions plus the fact that the liver of the human fetus probably can synthesize albumin and alpha and beta globulins at three to four months makes evaluation of placental transfer more difficult.

Studies of transfer of serum proteins in the rat have led to equivocal results. Halliday ('55) reports that gamma globulin can be transferred to the fetal circulation as early as the seventeenth day of gestation. Anderson ('59) reported that $\mathrm{I}^{131}$ labeled gamma globulin could be found radiographically in the yolk sac cavity but he did not report it as being found in the fetal circulation.

There appears to be no question that gamma globulin can pass freely from the maternal circulation to that of the fetus in the rabbit, guinea pig, monkey, and man; for the young are born with their full compliment of passive immunity, and this is not augmented after birth to any extent. In rats and mice probably some transmission occurs during the fetal period, but most occurs by way of the mother's milk after birth (Halliday, '55). Ruminants, horses, and pigs apparently obtain all passive immunity after birth (Hemmings and Brambell, '61). Transfer of albumin and alpha and beta globulins is not so well documented and conflicting reports have appeared (see discussion above). Since in the present study no attempt was made to tag the serum proteins of the mother no new information can be offered as to the transfer of serum proteins from mother to fetus in the rat. Nonetheless, several interesting observations can be made. Trypan blue is known to be bcund to albumin, even though weakly (Rawson, '43). While it has already been shown that this trypan blue-albumin complex presumably passes into the yolk sac cavity in the rabbit (Ferm, '56; Hommes, '59; Beaudoin and Ferm, '61) it is not known what effect trypan blue may have on the rate of transfer of the albumin into the fetal tissues. Should a reduction in rate be domonstrated, an explanation would be forthcoming for the fact that the results presented in this paper describe a situation in which fetuses from treated mothers have lower concentrations of albumin than fetuses from control mothers. This statement is not meant to exclude some other action of trypan blue. For instance, Nace ('53) postulated, from serological studies of the blood of the developing chick embryo, that transferred maternal serum proteins may serve as templates or models on which the embryo patterns its own serum proteins. Such a postulate, if true, could form the basis for an explanation of the fact that fetuses from trypan blue treated mothers had serum protein values different from the fetuses from untreated mothers, perhaps because of altered tem- 
plates for serum protein synthesis. Recently studies by Kelleher et al. ('63) have shown that the rat fetus can synthesize at least some of its serum proteins.

The observation that alpha-1 globulin and beta globulin have absolute concentrations lower in the experimental fetuses than in the controls is more difficult to analyze, in part due to the fact that trypan blue binds preferentially with albumin and only rarely with globulins. Several possible effects of trypan blue treatment are apparent: (1) an alteration in the serum proteins to form an abnormal protein as proposed by Yamada ('59), (2) an alteration in the transfer mechanism of the serum proteins, i.e., placental permeability, (3) an alteration in the utilization of the maternal proteins by the fetus, whether the protein be altered or normal, and (4) some other effect as yet unknown e.g., another metabolic effect. Alpha-1 globulin exhibits a marked rise in relative and absolute concentration in maternal serum a few days prior to term. This rise is not seen in trypan blue treated animals (Beaudoin, '63). Fetal alpha-1 globulin shows the same marked rise during the period, 17 days to parturition (Heim, '61) and, as shown in the present study, on the twentieth day. From these observations it can be inferred that there is free exchange between maternal and fetal alpha-1 globulins. This would explain the observation that fetuses from trypan blue treated mothers have a lower alpha-1 globulin concentration than the control fetuses, for their mothers have less alpha-1 globulin.

Beta globulin is known to increase following trypan blue treatment in the rabbit (Langman and van Druen, '59; Beaudoin and Ferm, '61). A similar phenomenon is observed in the rat (Beaudoin, unpublished), however, the cause of this rise in beta globulin is not known. The paradox exists that while fetal alpha-1 globulin concentration varies directly with the maternal alpha-1 globulin concentration, beta globulin values do not. For, in sipte of the absolute rise in beta globulin concentration in the trypan blue treated mother, the fetuses have beta globulin values lower than those found in the control fetuses. This suggests interference with the transport of maternal beta globulin to the fetus.
It is also possible that the beta globulin has become altered somehow so that it cannot behave in its usual manner, whatever that may be.

The results obtained in this investigation do not support the contention that an abnormal protein is produced following treatment with trypan blue, as proposed by Yamada ('59) and Paoletti et al. ('62). Six serum protein bands were discernible in both the mothers and fetuses of control and trypan blue treated rats (fig. 1). The alpha-2 globulin band is at times relatively faint in the adult female rat. It becomes more distinct following trypan blue treatment, which accounts for the relative in. crease in alpha-2 globulin, as demonstrated by the Spinco Analytrol. Both Yamada and Paoletti report only five serum protein fractions in their control animals and only after trypan blue treatment is the sixth or " $\mathrm{X}$ " fraction seen. It is quite possible that this band is the same band that is named alpha-2 globulin in the present study. Preliminary studies, in the author's laboratory, using male rats have demonstrated six serum protein components in the normal Wistar male.

Whatever the answer may be to this perplexing problem of trypan blue teratogenicity for the present one can only say that trypan blue can cause alterations in the maternal serum proteins, the yolk sac fluid proteins, and in the fetal serum proteins as well. The key to the teratogenic action of trypan blue may very well lie in the elucidation of its effect on maternal protein metabolism and subsequently on the interrelations between maternal and fetal protein metabolism.

\section{LITERATURE CITED}

Anderson, J. W. 1959 The placental barrier to gamma-globulins in the rat. Am. J. Anat., 104: 403-429.

Bangham, D. R., K. R. Hobbs and R. J. Terry 1958 Selective placental transfer of serumproteins in the rhesus. Lancet, 2: 351-354.

Beaudoin, A. R., and V. H. Ferm 1961 The effect of disazo dyes on protein metabolism in the pregnant rabbit. J. Exp. Zool., 147: 219225.

Beaudoin, A. R. 1963 Serum proteins during normal rat pregnancy and rat pregnancies in. sulated with a teratogen. Anat. Rec., 145: 205.

Brambell, F. W. R., and W. A. Hemmings 1949 The passage into the embryonic yolk-sac cavity 
of maternal plasma proteins in rabbits. $\mathrm{J}$. Physiol., 108: 177-185.

Brambell, F. W. R., W. A. Hemmings, M. Henderson and R. A. Kekwick 1953 Electrophoretic studies of serum proteins of foetal rabbits. Proc. R. Soc., London, Series B, 141: 300-314.

Dancis, J., M. Shafron and W. L. Money 1957 The transport of amino acids and plasma proteins across the placenta in the guinea pig. A. M. A. J. Dis. Child., 93: 8.

Dancis, J. 1962 The placenta in fetal nutrition and excretion. Am. J. Obst. \& Gynec., 84: 1749-1755.

Dijkstra, J., and J. Gillman 1960 Trypan blue concentration and protein composition in sera of rats injected repeatedly with trypan blue in relation to reticulosis and to reticulo-sarcoma. S. Afr. J. med. Sci., 25: 119-131.

Ferm, V. H. 1956 Permeability of the rabbit blastocyst to trypan blue. Anat. Rec., 125: 745-759.

Fox, M. H., and C. M. Goss 1956 Experimental production of a syndrome of congenital cardiovascular defects in rats. Anat. Rec., 124: 189-208.

Freda, V. J. 1962 Placental transfer of antibodies in man. Am. J. Obst. \& Gynec., 84: 1756-1777.

Halliday, R. 1955 Prenatal and postnatal transmission of passive immunity to young rats. Proc. R. Soc., London, Series B, 144: 427-430.

Heim, W. G. 1961 The serum proteins of the rat during development. J. Embryol. exp. Morph., 9: 52-59.

Hemmings, W. A., and F. W. R. Brambell 1961 Protein transfer across the foetal membranes. Brit. Med. Bull., 17: 96-103.

Hommes, O. R. 1959 Trypan blue in the rabbit. Acta Morph. Neerl. Scand., 2: 28-37.
Kekwick, R. A. 1959 The serum proteins of the fetus and young of some mammals. Adv. Prot. Chem., 14: 231-254.

Kelleher, P., and C. Villee 1962 Serum-protein changes in the fetal rat studied by immunoelectrophoresis. Biochim. Biophys. Acta, 59: 252-254.

Kelleher, P. C., C. D. Kenyon and C. A. Villee 1963 Serum protein synthesis by the fetal rat. Sci., 139: 839-840.

Langman, J., and $H$. van Drunen 1959 The effect of trypan blue upon maternal protein metabolism and embryonic development. Anat. Rec., 133: 513-526.

Leissring, J. C., and J. W. Anderson 1961 The transfer of serum proteins from mother to young in the guinea pig. I. Prenatal rates and routes. Am. J. Anat., 109: 149-156.

Nace, G. W. 1953 Serological studies of the blood of the developing chick embryo. J. Exp. Zool., 122: 423-428.

Paoletti, C., G. Riou and R. Truhaut 1962 Electrophoretic pattern of plasma proteins in rats treated with trypan blue and ethionine. $\mathrm{Na}$ ture, 193: 784-785.

Rawson, R. A. 1943 The binding of T-1824 and structurally related diazo dyes by the plasma proteins. Am. J. Physiol,, 138: 708717.

Smith, A. E. S., and A. M. Schechtman 1962 Significance of the rabbit yolk sac. A study of the passage of heterologous proteins from mother to embryo. Develop. Biol., 4: 339-360.

Sternberg, J. 1962 Placental transfers: modern methods of study. Am. J. Obst. \& Gynec., 84: 1731-1748.

Yamada, T. 1959 Abnormal serum protein observed in trypan blue-treated rats. Proc. Soc. Exp. Biol. \& Med., 101: 566-568. 